\title{
Palladium-catalyzed formal hydroacylation of allenes employing carboxylic anhydrides and hydrosilanes
}

\section{$\operatorname{AUTHOR}(\mathrm{S})$ :}

Fujihara, Tetsuaki; Hosomi, Takuro; Cong, Cong; Hosoki, Tomoya; Terao, Jun; Tsuji, Yasushi

\section{CITATION:}

Fujihara, Tetsuaki ...[et al]. Palladium-catalyzed formal hydroacylation of allenes employing carboxylic anhydrides and hydrosilanes. Tetrahedron 2015, 71(26-27): 45704574

\section{ISSUE DATE:}

2015-07-01

URL:

http://hdl.handle.net/2433/201514

\section{RIGHT:}

(c) 2015. This manuscript version is made available under the CC-BY-NC-ND 4.0 license

http://creativecommons.org/licenses/by-nc-nd/4.0/; The full-text file will be made open to the public on 01 July 2017 in accordance with publisher's 'Terms and Conditions for Self-Archiving'; この論文は出版社版でありません。引用の際に は出版社版をご確認じ利用ください。; This is not the published version. Please cite only the published version. 


\title{
Palladium-catalyzed formal hydroacylation of allenes employing carboxylic anhydrides and hydrosilanes
}

\author{
Tetsuaki Fujihara*, Takuro Hosomi, Cong Cong, Tomoya Hosoki, Jun Terao and Yasushi Tsuji* \\ Department of Energy and Hydrocarbon Chemistry, Graduate School of Engineering, Kyoto University, Kyoto 615-8510, Japan.
}

\section{ARTICLE INFO}

Article history:

Received

Received in revised form

Accepted

Available online

\section{Keywords:}

Allene

Carboxylic anhydride

Hydroacylation

Hydrosilane

Palladium

\section{ABSTRACT}

The formal hydroacylation reaction of allenes has been developed employing carboxylic anhydrides as acyl sources and hydrosilanes as reducing reagents in the presence of a commercially available palladium complex as a catalyst. The reaction affords $\alpha, \beta$-unsaturated ketones regio- and stereoselectively. The similar catalyst system is also effective for the reduction of carboxylic anhydrides to the corresponding aldehydes employing hydrosilanes.

\section{Introduction}

Hydroacylation reaction involving the addition of aldehydes to carbon-carbon multiple bonds is a useful synthetic method to provide unsymmetrical ketones atom-economically. ${ }^{1}$ However, intermolecular hydroacylation of alkenes and alkynes often suffers from low selectivity and low yields. In order to ensure high efficiency, i) intramolecular reaction, ${ }^{2}$ ii) substrates bearing suitable directing groups, ${ }^{3}$ and/or iii) carbon monoxide pressure, ${ }^{4}$ were often indispensable. An alternative method is a formal hydroacylation employing a suitable acyl source in place of an aldehyde. The oxidative or reductive formal hydroacylation employing alcohols as acyl donors were reported. ${ }^{5}$ We recently found the palladium-catalyzed formal hydroacylation of allenes employing acid chlorides and hydrosilanes. ${ }^{6}$ The reaction afforded the corresponding $\alpha, \beta$-unsaturated ketones regio- and stereoselectively.

Carboxylic anhydrides are stable, easy-to-handled, and easyto-prepare compounds from the corresponding carboxylic acids, and are one of the most useful compounds in organic synthesis. Regarding the transition-metal catalyzed reactions, it is known that the oxidative addition of the $\mathrm{C}(\mathrm{acyl})-\mathrm{O}$ bond proceeds in the presence of suitable transition-metal complexes. ${ }^{7}$ Thus, carboxylic anhydrides were used as an acyl source in the palladium-catalyzed cross-coupling reactions employing organoboronic acids ${ }^{8}$ and organozinc reagents. ${ }^{9}$ Carboxylic anhydrides were also utilized in the formal hydroacylation of styrene derivatives in the presence of a rhodium catalyst. ${ }^{10}$ However, a burnable hydrogen gas was used as a reducing agent.

Herein, we report the palladium-catalyzed formal hydroacylation of allenes employing carboxylic anhydrides with stable and easy-to-handle hydrosilanes as a reducing agent. As for the hydroacylation of allenes using aldehydes, ${ }^{11}$ there have been only two precedents to date, in which the aldehydes must bear hydroxyl ${ }^{11 \mathrm{a}}$ or thioether ${ }^{11 \mathrm{~b}}$ functionalities as directing groups. Noteworthy is that no directing groups are necessary in the present reaction.

\section{Palladium-catalyzed reduction of carboxylic anhydrides}

Before investigating the formal hydroacylation of allenes, we carried out reduction of carboxylic anhydrides to aldehydes employing hydrosilanes as a reducing agent. Yamamoto and coworkers carried out the reduction of carboxylic anhydrides to the corresponding aldehydes in the presence of palladium catalysts. ${ }^{12}$ However, the reaction required high pressure $(3.0 \mathrm{MPa})$ of molecular hydrogen. Based on our previous report that a palladium complex efficiently catalyzes the reduction of carboxylic acids in the presence of pivalic anhydride, ${ }^{13} \mathrm{Pd}-$ catalyzed reduction of carboxylic anhydrides employing hydrosilanes to the corresponding aldehydes was carried out. Thus, benzoyl anhydride (1a) was treated with a mixture of $\mathrm{Pd}(\mathrm{dba})_{2}$ and $\mathrm{P}\left(p-\mathrm{MeOC}_{6} \mathrm{H}_{4}\right)_{3}$ as a catalyst in the presence of

\footnotetext{
* Corresponding author. Tel.: +81-75-383-2515; fax: +81-75-383-2514; e-mail: ytsuji@ scl.kyoto-u.ac.jp

* Corresponding author. Tel.: +81-75-383-2517; fax: +81-75-383-2514; e-mail: tfuji@ scl.kyoto-u.ac.jp
} 
Table 1

Effect of ligands and hydrosilanes on the palladium-catalyzed reduction of benzoic anhydride $(\mathbf{1 a})^{a}$

\begin{tabular}{|c|c|c|c|}
\hline Entry & Ligand & Hydrosilane & Yield $(\%)^{b}$ \\
\hline 1 & $\mathrm{P}\left(p-\mathrm{MeOC}_{6} \mathrm{H}_{4}\right)_{3}$ & $\mathrm{H}_{2} \mathrm{SiMePh}$ & 85 \\
\hline 2 & none & $\mathrm{H}_{2} \mathrm{SiMePh}$ & trace \\
\hline 3 & $\mathrm{PPh}_{3}$ & $\mathrm{H}_{2} \mathrm{SiMePh}$ & 68 \\
\hline 4 & $\mathrm{P}\left(p-\mathrm{MeC}_{6} \mathrm{H}_{4}\right)_{3}$ & $\mathrm{H}_{2} \mathrm{SiMePh}$ & 74 \\
\hline 5 & $\mathrm{PCy}_{3}$ & $\mathrm{H}_{2} \mathrm{SiMePh}$ & 66 \\
\hline 6 & $\mathrm{P}\left(p-\mathrm{MeOC}_{6} \mathrm{H}_{4}\right)_{3}$ & $\mathrm{HSiEt}_{3}$ & 67 \\
\hline 7 & $\mathrm{P}\left(p-\mathrm{MeOC}_{6} \mathrm{H}_{4}\right)_{3}$ & $\mathrm{HSi}^{i} \mathrm{Pr}_{3}$ & 14 \\
\hline 8 & $\mathrm{P}\left(p-\mathrm{MeOC}_{6} \mathrm{H}_{4}\right)_{3}$ & $\mathrm{H}_{2} \mathrm{SiEt}_{2}$ & 74 \\
\hline 9 & $\mathrm{P}\left(p-\mathrm{MeOC}_{6} \mathrm{H}_{4}\right)_{3}$ & $\mathrm{H}_{2} \mathrm{SiPh}_{2}$ & 9 \\
\hline $10^{c}$ & $\mathrm{P}\left(p-\mathrm{MeOC}_{6} \mathrm{H}_{4}\right)_{3}$ & $\mathrm{H}_{2} \mathrm{SiMePh}$ & 81 \\
\hline \multicolumn{4}{|c|}{$\begin{array}{l}{ }^{a} \text { Reaction conditions: benzoic anhydride }(1 \mathrm{a}: 0.50 \mathrm{mmol}) \text {, } \\
\text { hydrosilane }(0.55 \mathrm{mmol}), \mathrm{Pd}(\mathrm{dba})_{2}(0.025 \mathrm{mmol}, 5.0 \mathrm{~mol} \%) \text {, ligand } \\
(0.05 \mathrm{mmol}, 10 \mathrm{~mol} \%, \mathrm{P} / \mathrm{Pd}=2) \text { in toluene }(1.0 \mathrm{~mL}) \text { at } 50{ }^{\circ} \mathrm{C} \text { for } 20 \\
\text { h. }{ }^{b} \text { Yield based on the } \mathrm{GC} \text { internal standard technique. }{ }^{c} \mathrm{MeCN}(1.0 \\
\mathrm{mL}) \text { was used as the solvent. }\end{array}$} \\
\hline
\end{tabular}

Table 2

The palladium-catalyzed reduction of carboxylic anhydrides to the corresponding aldehydes ${ }^{a}$

\begin{tabular}{|c|c|c|c|}
\hline Entry & Carboxylic anhydride (1) & Temp. $\left({ }^{\circ} \mathrm{C}\right)$ & $\begin{array}{l}\text { Yield } \\
(\%)^{b}\end{array}$ \\
\hline 1 & & 50 & 2b: 83 \\
\hline $2^{c}$ & & 40 & 2c: 52 \\
\hline 3 & & 40 & 2d: 75 \\
\hline 4 & & 60 & 2e: 76 \\
\hline 5 & & 40 & 2f: 70 \\
\hline 6 & 9 & 50 & $2 \mathrm{~g}: 88^{d}$ \\
\hline 7 & $15 \quad \mathbf{~ h h}$ & 50 & $\mathbf{2 h}: 93^{d}$ \\
\hline 8 & & 60 & $2 \mathbf{i}: 82$ \\
\hline 9 & & 120 & $2 \mathbf{j}: 73^{d}$ \\
\hline
\end{tabular}

${ }^{a}$ Reaction conditions: carboxylic anhydride (1: $\left.0.50 \mathrm{mmol}\right)$, $\mathrm{H}_{2} \mathrm{SiMePh}(0.55 \mathrm{mmol}), \mathrm{Pd}(\mathrm{dba})_{2}(0.025 \mathrm{mmol}, 5.0 \mathrm{~mol} \%), \mathrm{P}(p-$ $\left.\mathrm{MeOC}_{6} \mathrm{H}_{4}\right)_{3}(0.050 \mathrm{mmol}, 10 \mathrm{~mol} \%, \mathrm{P} / \mathrm{Pd}=2)$ in toluene $(1.0 \mathrm{~mL})$, for $20 \mathrm{~h} .{ }^{b}$ Isolated yield. ${ }^{c} \mathrm{Pd}(\mathrm{dba})_{2}(0.05 \mathrm{mmol}, 10 \mathrm{~mol} \%), \mathrm{P}(p-$ $\left.\mathrm{MeOC}_{6} \mathrm{H}_{4}\right)_{3}(0.10 \mathrm{mmol}, 20 \mathrm{~mol} \%, \mathrm{P} / \mathrm{Pd}=2) .{ }^{d}$ Yield based on the GC internal standard technique.

$\mathrm{H}_{2} \mathrm{SiMePh}$ as a reducing agent in toluene at $50{ }^{\circ} \mathrm{C}$ (Table 1). As a result, benzaldehyde (2a) was obtained in $85 \%$ yield (entry 1 ). Without the ligand, 1a did not convert at all (entry 2). As the ligand, $\mathrm{PPh}_{3}, \mathrm{P}\left(p-\mathrm{MeC}_{6} \mathrm{H}_{4}\right)_{3}$ and $\mathrm{PCy}_{3}$ also afforded $\mathbf{2 a}$ in good yields (entries 3-5). As for hydrosilanes, $\mathrm{HSiEt}_{3}$ afforded $\mathbf{2 a}$ in $67 \%$ yield, while more bulky $\mathrm{HSi}^{i} \mathrm{Pr}_{3}$ was not efficient (entries 6 and 7). $\mathrm{H}_{2} \mathrm{SiEt}_{2}$ and $\mathrm{H}_{2} \mathrm{SiPh}_{2}$ provided $2 \mathrm{a}$ in $74 \%$ and $9 \%$ yields, respectively (entries 8 and 9). MeCN was also a good solvent in the reaction (entry 10).

Various carboxylic anhydrides were smoothly converted to the corresponding aldehydes in good to high yields (Table 2). Among them, the reaction of an aromatic acid anhydride having an electron donating group (-OMe) proceeded smoothly, giving the corresponding aldehyde in $83 \%$ yield (entry 1 ). In the reaction of $\mathbf{1 c}$ bearing an electron withdrawing group $\left(-\mathrm{CF}_{3}\right), \mathbf{2 c}$ was isolated in 52\% yield (entry 2). 3-Pyridinecarboxylic anhydride 1d gave 2d in good yield (entry 3). With 3arylpropionic acid anhydrides (1e and 1f), the desired aldehydes (2e and 2f) were obtained in good yields (entries 4-5). Other aliphatic acid anhydrides such as $\mathbf{1 g}, \mathbf{1 h}$, and $\mathbf{1 i}$ also converted to the corresponding aldehydes in $88 \%, 93 \%$, and $82 \%$ yields, respectively (entries 6-8). In addition, cyclohexanecarboxylic anhydride $\mathbf{1} \mathbf{j}$ also afforded $\mathbf{2} \mathbf{j}$ in $73 \%$ yield by elevating the reaction temperature to $120{ }^{\circ} \mathrm{C}$ (entry 9). Unfortunately, pivalic anhydride could not be employed as the substrate in the present catalytic system possibly because of its steric hindrance.

\section{Palladium-catalyzed formal hydroacylation of allenes}

As mentioned above, a hydrosilane is an excellent reducing reagent for the reduction of carboxylic anhydrides. Thus, the formal hydroacylation of cyclohexylallene (3a) with 1a was carried out using $\mathrm{HSi}^{i} \mathrm{Pr}_{3}$ as a reducing agent in the presence of a catalytic amount of $\mathrm{PdCl}_{2}(\mathrm{MeCN})_{2}$ in $\mathrm{MeCN}$ at $50{ }^{\circ} \mathrm{C}$ (Table 3). Under the reaction conditions, an $E / Z$ mixture of hydroacylated product (4a) was obtained in $96 \%$ total yield with good $E$ selectivity $(E / Z=88 / 12$, entry 1$)$. By column chromatography, pure $(E)-4 a$ was isolated in $71 \%$ yield. In this reaction, the addition of auxiliary ligands such as $\mathrm{PPh}_{3}$ inhibited the formation of 4a (entry 2). As for hydrosilane, $\mathrm{HSiEt}_{3}, \mathrm{HSiPh}_{3}$ and $\mathrm{HSi}(\mathrm{OEt})_{3}$ were not effective (entries $\left.3-5\right) . \mathrm{PhCN}$ as a solvent provided $\mathbf{4 a}$ in $72 \%$, while DMF and THF were not suitable for this reaction (entries 6-8).

Next, the formal hydroacylation of several allenes (3) with

\section{Table 3}

Optimization of reaction conditions on the palladium-catalyzed formal hydroacylation of cyclohexylallene (3a) with $\mathbf{1} \mathbf{a}^{a}$

\begin{tabular}{|c|c|c|c|c|}
\hline Entry & Hydrosilane & Solvent & $\begin{array}{l}\text { Total yield } \\
(\mathbf{4 a})(\%)^{b}\end{array}$ & $\begin{array}{l}\text { Selectivity } \\
(E / Z)^{c}\end{array}$ \\
\hline 1 & $\mathrm{HSi}^{i} \mathrm{Pr}_{3}$ & $\mathrm{MeCN}$ & $96(71)^{d}$ & $88 / 12$ \\
\hline $2^{e}$ & $\mathrm{HSi}^{i} \mathrm{Pr}_{3}$ & $\mathrm{MeCN}$ & 0 & -- \\
\hline 3 & $\mathrm{HSiEt}_{3}$ & $\mathrm{MeCN}$ & 37 & $88 / 12$ \\
\hline 4 & $\mathrm{HSiPh}_{3}$ & $\mathrm{MeCN}$ & 20 & $86 / 14$ \\
\hline 5 & $\mathrm{HSi}(\mathrm{OEt})_{3}$ & $\mathrm{MeCN}$ & 39 & $78 / 22$ \\
\hline 6 & $\mathrm{HSi}^{i} \mathrm{Pr}_{3}$ & $\mathrm{PhCN}$ & 81 & $89 / 11$ \\
\hline 7 & $\mathrm{HSi}^{i} \mathrm{Pr}_{3}$ & DMF & 29 & $86 / 14$ \\
\hline 8 & $\mathrm{HSi}^{i} \mathrm{Pr}_{3}$ & THF & 7 & -- \\
\hline
\end{tabular}

mmol), hydrosilane $(0.65 \mathrm{mmol}), \mathrm{PdCl}_{2}(\mathrm{MeCN})_{2} \quad(0.025 \mathrm{mmol}, 5.0$ mol \%), solvent $(1.0 \mathrm{~mL})$ at $50{ }^{\circ} \mathrm{C}$ for $20 \mathrm{~h} .{ }^{b}$ Based on the $\mathrm{GC}$ internal standard technique. ${ }^{c}$ Determined by GC and GC-MS analysis. ${ }^{d}$ Isolated yield of $(E)-\mathbf{4 a} .{ }^{e} \mathrm{PPh}_{3}(0.050 \mathrm{~mol})$ was added.

carboxylic anhydrides (1) was carried out under the same reaction conditions as in entry 1 , Table 3 (Table 4 ). The reaction 
Table 4

The palladium-catalyzed formal hydroacylation of allenes ${ }^{a}$

\begin{tabular}{|c|c|c|c|}
\hline Entry & $\begin{array}{l}\text { Carboxylic } \\
\text { anhydride (1) }\end{array}$ & Allene (3) & $\begin{array}{l}\text { Yield of }(E)-\mathbf{4}(\%)^{b} \\
(E / Z \text { ratio in crude })^{c}\end{array}$ \\
\hline 1 & $1 \mathrm{c}$ & $3 \mathbf{a}$ & 4b: 81 (93/7) \\
\hline 2 & $1 b$ & $\mathbf{3 a}$ & 4c: $41(84 / 16)$ \\
\hline $3^{d}$ & 1e & 3a & 4d: 81 (94/6) \\
\hline 4 & $1 \mathbf{a}$ & $\mathbf{3 b}$ & 4e: 40 (91/9) \\
\hline 5 & $1 \mathbf{a}$ & $3 c$ & 4f: 73 \\
\hline
\end{tabular}

${ }^{a}$ Reaction conditions: anhydride $(\mathbf{1}, 0.50 \mathrm{mmol})$, allene $(\mathbf{3}, 1.0$ $\mathrm{mmol})$, triisopropylsilane $(0.65 \mathrm{mmol}), \mathrm{PdCl}_{2}(\mathrm{MeCN})_{2}(0.025 \mathrm{mmol}, 5.0$ mol \%), MeCN (1.0 mL) at $50{ }^{\circ} \mathrm{C}$ for $20 \mathrm{~h} .{ }^{b}$ Isolate yield of $(E)-4 .{ }^{c} E / Z$ ratio of crude reaction mixture by GC and GC-MS analysis. ${ }^{d} 10 \mathrm{~mol} \%$ catalyst was used.

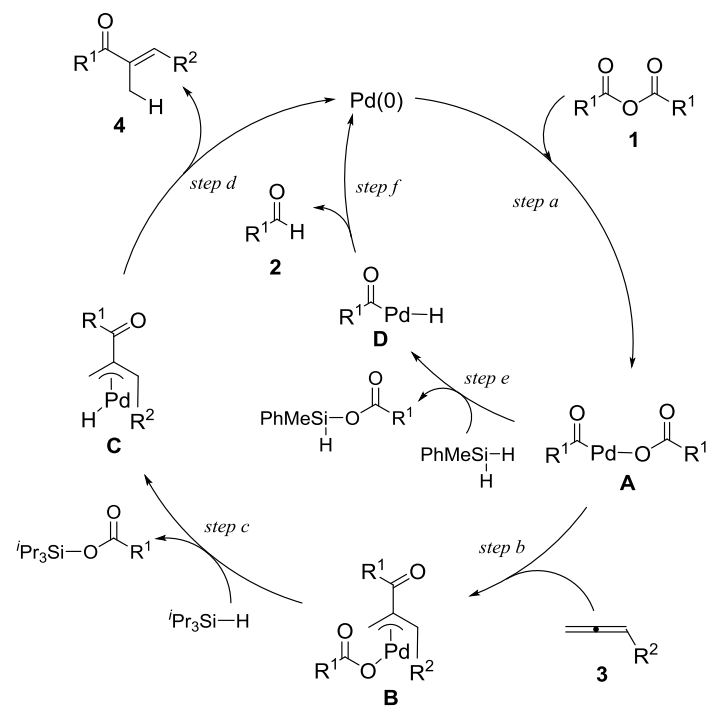

Scheme 1. Proposed mechanism.

of 3a with an aromatic carboxylic anhydride bearing electron withdrawing groups $\left(-\mathrm{CF}_{3}\right)$ gave $(E)-\mathbf{4 b}$ in high yield (entry 1 ). On the other hand, an aromatic carboxylic anhydride with electron donating groups (-OMe) afforded the $\alpha, \beta$-unsaturated ketones $(\mathbf{4 c})$ in moderate yield with lower $E / Z$ selectivity (entry 2 ). The reaction of 3-phenylpropionic anhydride (1e) gave the corresponding product (4d) in $81 \%$ yield in the presence of 10 mol $\%$ palladium catalyst (entry 3$)$. The reaction of 1-(2- phenylethyl)allene (3b) with 1a afforded the corresponding $\alpha, \beta$-unsaturated ketone (E)-4e in $40 \%$ yield (entry 4 ). Gratifyingly, 1,1-disubstituted allene (3c) also provided the desired product (4f) in good yield (entry 5). Unfortunately, the formal hydroacylation of 1-phenylallene only afforded the corresponding product in poor yields.

As for reaction mechanism, the reduction of 1 employing hydrosilanes would share several catalytic steps with the formal hydroacylation of $\mathbf{3}$ with $\mathbf{1}$ (Scheme 1). The oxidative addition of the $\operatorname{Pd}(0)$ active catalyst species to a carbon-oxygen bond of $\mathbf{1}$ affords an acyl palladium species $\mathbf{A}$ (step a). ${ }^{14}$ In the formal hydroacylation of $\mathbf{3}$, the insertion of $\mathbf{3}$ to the palladium-carbon bond of $\mathbf{A}$ gives an allyl palladium intermediate $\mathbf{B}$ (step b). Then, reaction of $\mathbf{B}$ with hydrosilane affords an allylhydrido intermediate $\mathbf{C}$ (step c). Finally, the reductive elimination affords $\alpha, \beta$-unsaturated ketone (4) as the product, and the $\operatorname{Pd}(0)$ catalyst species regenerates (step d). In the reduction of $\mathbf{1}, \mathbf{A}$ reacts with hydrosilane directly, giving an acylhydrido intermediate D (step e). The reductive elimination of $\mathbf{D}$ affords aldehyde (2) as the product and the $\operatorname{Pd}(0)$ species regenerates (step f).

\section{Conclusions}

We found that hydrosilanes are versatile reducing reagents in the formal hydroacylation reaction of allenes using carboxylic anhydrides as an acyl source in the presence of a commercially available palladium complex as a catalyst. The reactions afforded $\alpha, \beta$-unsaturated ketones regio- and stereoselectively. In the presence of the similar catalyst system, the reduction of carboxylic anhydrides to the corresponding aldehydes proceeded effectively.

\section{Experimental section}

\subsection{General}

All manipulations were performed under an argon atmosphere using standard Schlenk-type glassware on a dualmanifold Schlenk line. Solvents were dried and purified before use by usual methods. ${ }^{15}{ }^{1} \mathrm{H}$ NMR and ${ }^{13} \mathrm{C}$ NMR spectra were measured with a JEOL ECX-400P spectrometer. The ${ }^{1} \mathrm{H}$ NMR chemical shifts are reported relative to tetramethylsilane (TMS, $0.00 \mathrm{ppm})$. The ${ }^{13} \mathrm{C}$ NMR chemical shifts are reported relative to $\mathrm{CDCl}_{3}$ (77.0 ppm). GC analysis was carried out using Shimadzu GC-17A equipped with an integrator (C-R8A) with a capillary column (CBP-1, $0.25 \mathrm{~mm}$ i.d. $\times 25 \mathrm{~m}$ ). Medium-pressure column chromatography (MPLC) was performed with a Biotage IsoleraOne (SNAP Ultra 25g). Column chromatography was carried out on silica gel (Kanto N60, spherical, neutral, 63-210 $\mu \mathrm{m})$. TLC analyses were performed on commercial glass plates bearing a $0.25-\mathrm{mm}$ layer of Merck Silica gel 60F254. Unless otherwise noted, materials obtained from the commercial suppliers were used without further purification.

\subsection{General procedure for the palladium-catalyzed reduction of carboxylic anhydrides (Table 1 and Table 2)}

To a $10 \mathrm{~mL}$ Schlenk flask with a magnetic stir bar, a carboxylic anhydride $(\mathbf{1}, 0.50 \mathrm{mmol}), \mathrm{Pd}(\mathrm{dba})_{2}(0.025 \mathrm{mmol})$ and $\mathrm{P}\left(p-\mathrm{OMeC}_{6} \mathrm{H}_{4}\right)_{3} \quad(0.050 \mathrm{mmol})$ were added. The flask was evacuated and backfilled with argon three times. Then, toluene $(1.0 \mathrm{~mL})$ was added to the flask and the resultant solution was stirred at room temperature for $10 \mathrm{~min}$. After $\mathrm{H}_{2} \mathrm{SiMePh}(0.55$ mmol) was added to the flask, the reaction mixture was stirred at $40-120{ }^{\circ} \mathrm{C}$ for $20 \mathrm{~h}$ under an argon atmosphere. The reaction 
mixture was cooled to room temperature, the yield of aldehyde (2) was determined by GC analysis or the product was isolated with silica gel column chromatography. The yields of $\mathbf{2 a}, \mathbf{2 g}, \mathbf{2 h}$, and $2 \mathbf{j}$ were determined by GC analysis based on the internal standard technique. ${ }^{1} \mathrm{H}$ and ${ }^{13} \mathrm{C}$ NMR spectra of isolated $\mathbf{2 b}, \mathbf{2 c}$, $\mathbf{2 d}, \mathbf{2 e}, \mathbf{2} \mathbf{f}$, and $\mathbf{2 i}$ were good agreement with reported data. ${ }^{13,16}$

5.2.1. 4-Methoxybenzaldehyde (2b):

Pale yellow oil (57 mg, 83\%), ${ }^{1} \mathrm{H}$ NMR (400 $\left.\mathrm{MHz}, \mathrm{CDCl}_{3}\right): \delta$ $9.89(\mathrm{~s}, 1 \mathrm{H}), 7.85-7.83(\mathrm{~d}, J=8.8 \mathrm{~Hz}, 2 \mathrm{H}), 7.01(\mathrm{~d}, J=8.8 \mathrm{~Hz}$, $2 \mathrm{H}), 3.90(\mathrm{~s}, 3 \mathrm{H})$

\subsubsection{4-Trifluoromethylbenzaldehyde (2c):}

Pale yellow oil (45 mg, 52\%), ${ }^{1} \mathrm{H}$ NMR $\left(400 \mathrm{MHz}, \mathrm{CDCl}_{3}\right): \delta$ $10.11(\mathrm{~s}, 1 \mathrm{H}), 8.01(\mathrm{~d}, J=8.4 \mathrm{~Hz}, 2 \mathrm{H}), 7.81(\mathrm{~d}, J=8.0 \mathrm{~Hz}, 2 \mathrm{H})$.

5.2.3. 3-Pyridinecarboaldehyde (2d):

Colorless solid (42 mg, 75\%), ${ }^{1} \mathrm{H}$ NMR (400 MHz, $\left.\mathrm{CDCl}_{3}\right): \delta$ $10.14(\mathrm{~s}, 1 \mathrm{H}), 9.11(\mathrm{~s}, 1 \mathrm{H}), 8.87-8.85(\mathrm{~m}, 1 \mathrm{H}), 8.21-8.17(\mathrm{~m}, 1 \mathrm{H})$, 7.53-7.50 (m, 1H).

\subsubsection{3-Phenyl-1-propanal (2e):}

Pale yellow oil (51 mg, 76\%), ${ }^{1} \mathrm{H} \mathrm{NMR}\left(400 \mathrm{MHz}, \mathrm{CDCl}_{3}\right)$ : $\delta 9.82(\mathrm{~s}, 1 \mathrm{H}), 7.29(\mathrm{t}, J=7.6 \mathrm{~Hz}, 2 \mathrm{H}), 7.21(\mathrm{t}, J=8.0 \mathrm{~Hz}, 3 \mathrm{H})$, $2.96(\mathrm{t}, J=8.0 \mathrm{~Hz}, 2 \mathrm{H}), 2.78(\mathrm{t}, J=7.6 \mathrm{~Hz}, 2 \mathrm{H})$

5.2.5. 3-(4-Chlorophenyl)-1-propanal (2f):

Pale yellow oil (119 mg, 70\%), ${ }^{1} \mathrm{H}$ NMR (400 MHz, $\left.\mathrm{CDCl}_{3}\right): \delta$ $9.80(\mathrm{~m}, 1 \mathrm{H}), 7.25(\mathrm{~d}, J=8.4 \mathrm{~Hz}, 2 \mathrm{H}), 7.12(\mathrm{~d}, J=8.8 \mathrm{~Hz}, 2 \mathrm{H})$, $2.92(\mathrm{t}, J=7.6 \mathrm{~Hz}, 2 \mathrm{H}), 2.78-2.74(\mathrm{~m}, 2 \mathrm{H})$.

\subsubsection{Tetradecanal (2i):}

White solid (90 mg, 82\%), ${ }^{1} \mathrm{H}$ NMR $\left(400 \mathrm{MHz}, \mathrm{CDCl}_{3}\right): \delta 9.76(\mathrm{t}$, $J=1.4 \mathrm{~Hz}, 1 \mathrm{H}), 2.42(\mathrm{td}, J=7.6,2.0 \mathrm{~Hz}, 2 \mathrm{H}), 1.66-1.59(\mathrm{~m}, 2 \mathrm{H})$, $1.34-1.23(\mathrm{~m}, 20 \mathrm{H}), 0.88(\mathrm{t}, J=6.8 \mathrm{~Hz}, 3 \mathrm{H})$.

5.3. General procedure for the palladium-catalyzed formal hydroacylation of allenes (Table 3 and Table 4)

To a $10 \mathrm{~mL}$ Schlenk flask with a magnetic stir bar, a carboxylic anhydride $(\mathbf{1}, 0.50 \mathrm{mmol}), \mathrm{PdCl}_{2}(\mathrm{MeCN})_{2}(0.025$ mmol, $5.0 \mathrm{~mol} \%$ ) were added. The flask was evacuated and backfilled with argon three times. Then, MeCN $(1.0 \mathrm{~mL})$ and an allene $(3,1.0 \mathrm{mmol})$ were added to the flask and the resultant solution was stirred at room temperature for $10 \mathrm{~min}$. After triisopropylsilane $(0.65 \mathrm{mmol})$ was added, the reaction mixture was stirred at $50{ }^{\circ} \mathrm{C}$ for $20 \mathrm{~h}$ under an argon atmosphere. After the reaction mixture was cooled to room temperature, the products were isolated either by silica gel column chromatography or MPLC. ${ }^{1} \mathrm{H}$ and ${ }^{13} \mathrm{C}$ NMR spectra of isolated $4 \mathbf{a}-\mathbf{d}$ were good agreement with reported data. ${ }^{6}$

\subsection{1. (E)-3-Cyclohexyl-2-methyl-1-phenylprop-2- en-1-one $(4 a)$ :}

Colorless oil (81 mg, 71\%), ${ }^{1} \mathrm{H}$ NMR $\left(400 \mathrm{MHz}, \mathrm{CDCl}_{3}\right): \delta 7.62$ $(\mathrm{dt}, J=6.8,1.4 \mathrm{~Hz}, 2 \mathrm{H}), 7.48(\mathrm{tt}, J=7.5,1.4 \mathrm{~Hz}, 1 \mathrm{H}), 7.40(\mathrm{t}, J=$ $7.5 \mathrm{~Hz}, 2 \mathrm{H}), 6.11(\mathrm{dd}, J=9.5,1.4 \mathrm{~Hz}, 1 \mathrm{H}), 2.46(\mathrm{tdt}, J=10.9$, $9.5,3.6 \mathrm{~Hz}, 1 \mathrm{H}), 1.98(\mathrm{~d}, J=1.4 \mathrm{~Hz}, 3 \mathrm{H}), 1.77-1.63(\mathrm{~m}, 5 \mathrm{H})$, $1.39-1.04(\mathrm{~m}, 5 \mathrm{H})$.

\subsection{2. (E)-3-Cyclohexyl-2-methyl-1-[4-}

(trifluoromethyl)phenyl]prop-2-en-1-one (4b):

Pale yellow oil $(121 \mathrm{mg}, 81 \%),{ }^{1} \mathrm{H}$ NMR $(400 \mathrm{MHz}$, $\left.\mathrm{CDCl}_{3}\right): \delta 7.72-7.64(\mathrm{~m}, 4 \mathrm{H}), 6.10(\mathrm{dd}, J=9.5,1.4$ $\mathrm{Hz}, 1 \mathrm{H}), 2.48(\mathrm{tdt}, J=11.1,9.5,3.4 \mathrm{~Hz}, 1 \mathrm{H}), 1.99$ $(\mathrm{d}, J=1.4 \mathrm{~Hz}, 3 \mathrm{H}), 1.79-1.64(\mathrm{~m}, 5 \mathrm{H}), 1.41-1.02$ $(\mathrm{m}, 5 \mathrm{H})$.
5.3.3. (E)-3-Cyclohexyl-1-(4-methoxyphenyl)-2methylprop-2-en-1-one $(4 \mathrm{c})$ :

Pale yellow oil (54 mg, 41\%), ${ }^{1} \mathrm{H}$ NMR (400 $\mathrm{MHz}, \mathrm{CDCl}_{3}$ ): $\delta 7.67(\mathrm{dt}, J=9.2,2.5 \mathrm{~Hz}, 2 \mathrm{H}), 6.91(\mathrm{dt}, J=9.4,2.5 \mathrm{~Hz}, 2 \mathrm{H})$, 6.04 (dd, $J=9.5,1.4 \mathrm{~Hz}, 1 \mathrm{H}), 3.86(\mathrm{~s}, 3 \mathrm{H}), 2.45$ (tdt, $J=11.1$, 9.5, $3.6 \mathrm{~Hz}, 1 \mathrm{H}), 1.96(\mathrm{~d}, J=1.4 \mathrm{~Hz}, 3 \mathrm{H}), 1.78-1.62(\mathrm{~m}, 5 \mathrm{H})$, $1.40-1.04(\mathrm{~m}, 5 \mathrm{H})$.

\subsection{4. (E)-1-Cyclohexyl-2-methyl-5-phenylpent-1-} en-3-one $(4 d)$ :

Pale yellow oil (105 mg, 81\%), ${ }^{1} \mathrm{H}$ NMR $\left(\mathrm{CDCl}_{3}\right): \delta 7.31-7.25(\mathrm{~m}$, 2H), 7.22-7.16 (m, 3H), 6.39 (dd, $J=9.1,1.4 \mathrm{~Hz}, 1 \mathrm{H}), 3.00-2.89$ $(\mathrm{m}, 4 \mathrm{H}), 2.36(\mathrm{tdt}, J=11.1,9.5,3.8 \mathrm{~Hz}, 1 \mathrm{H}), 1.79(\mathrm{~d}, J=1.4 \mathrm{~Hz}$, $3 \mathrm{H}), 1.77-1.61(\mathrm{~m}, 5 \mathrm{H}), 1.37-1.01(\mathrm{~m}, 5 \mathrm{H})$.

\subsection{5. (E)-2-Methyl-1,5-diphenylhept-2-en-1-one} $(4 e)$ :

Colorless oil (51 mg, 40\%), ${ }^{1} \mathrm{H}$ NMR $\left(400 \mathrm{MHz}, \mathrm{CDCl}_{3}\right): \delta 7.53$ $(\mathrm{dt}, J=8.1,1.1 \mathrm{~Hz}, 2 \mathrm{H}), 7.47(\mathrm{tt}, J=7.2,1.4 \mathrm{~Hz}, 1 \mathrm{H}), 7.36(\mathrm{t}, J=$ $7.5 \mathrm{~Hz}, 2 \mathrm{H}), 7.29$ (t, $J=7.2 \mathrm{~Hz}, 2 \mathrm{H}), 7.23-7.15(\mathrm{~m}, 3 \mathrm{H}), 6.28(\mathrm{tq}$, $J=7.2,1.4 \mathrm{~Hz}, 1 \mathrm{H}), 2.75(\mathrm{t}, J=7.5 \mathrm{~Hz}, 2 \mathrm{H}), 2.60(\mathrm{td}, J=7.5$, $7.2 \mathrm{~Hz}, 2 \mathrm{H}), 1.91(\mathrm{~s}, 3 \mathrm{H}) .{ }^{13} \mathrm{C}$ NMR $\left(100 \mathrm{MHz}, \mathrm{CDCl}_{3}\right): \delta 198.8$, $145.0,141.0,138.5,136.9,131.3,129.2,128.4,128.3,127.9$, 126.1, 34.6, 30.7, 12.4. HRMS $(\mathrm{m} / \mathrm{z})$ : $[\mathrm{M}+\mathrm{H}]^{+}$calcd for $\mathrm{C}_{18} \mathrm{H}_{18} \mathrm{O}$ : 250.1358. Found: 250.1360 .

\subsubsection{2-Cyclohexylidene-1-phenylpropan-1-one} $(4 f)$ :

Colorless oil (73 mg, 73\%), ${ }^{1} \mathrm{H}$ NMR (400 MHz, $\left.\mathrm{CDCl}_{3}\right): \delta 7.92$ $(\mathrm{dt}, J=6.6,1.6 \mathrm{~Hz}, 2 \mathrm{H}), 7.54(\mathrm{tt}, J=7.2,1.6 \mathrm{~Hz}, 1 \mathrm{H}), 7.45(\mathrm{t}, J=$ $7.5 \mathrm{~Hz}, 2 \mathrm{H}), 2.30(\mathrm{t}, J=6.1 \mathrm{~Hz}, 2 \mathrm{H}), 1.98(\mathrm{t}, J=5.7 \mathrm{~Hz}, 2 \mathrm{H})$, $1.87(\mathrm{~s}, 3 \mathrm{H}), 1.69-1.62(\mathrm{~m}, 2 \mathrm{H}), 1.59-1.52(\mathrm{~m}, 2 \mathrm{H}), 1.47-1.39(\mathrm{~m}$, 2H). $\left.{ }^{13} \mathrm{C} \mathrm{NMR} \mathrm{(100} \mathrm{MHz,} \mathrm{CDCl}_{3}\right): \delta 201.9,140.2,136.9,133.0$, 129.3, 128.6, 126.2, 32.8, 29.9, 27.7, 27.6, 26.4, 15.7. HRMS $(\mathrm{m} / \mathrm{z}):[\mathrm{M}+\mathrm{H}]^{+}$calcd for for $\mathrm{C}_{15} \mathrm{H}_{18} \mathrm{O}: 214.1358$. Found: 214.1358 .

\section{Acknowledgments}

This work was supported by Grant-in-Aid for Scientific Research (A) and also by Grant-in-Aid for Scientific Research on Innovative Areas ("Molecular activation directed toward straightforward synthesis") from MEXT, Japan.

\section{References and notes}

1. For reviews, see: (a) Willis, M. C. Chem. Rev. 2010, 110, 725-748. (b) Leung, J. C.; Krische, M. J.; Chem. Sci. 2012, 3, 2202-2209. (c) Park, Y. J.; Park, J.-W.; Jun, C.-H. Acc. Chem. Res. 2008, 41, 222-234. (d) Jun, C.-H.; Jo, E.-A.; Park, J.-W. Eur. J. Org. Chem. 2007, 1869-1881. (e) Fu, G. C.; In Modern Rhodium-Catalyzed Organic Reactions, Evans. A. ed.; Wiley-VCH: Weinheim, 2005; pp. 79-91.

2. Selected examples for intramolecular hydroacylations, see: (a) Hoshimoto, Y.; Hayashi, Y.; Suzuki, H.; Ohashi, M.; Ogoshi, S. Angew. Chem., Int. Ed. 2012, 51, 10812-10815. (b) Coulter, M. M.; Dornan, P. K.; Dong, V. M. J. Am. Chem. Soc. 2009, 131, 6932-6933. (b) Kundu, K.; McCullagh, J. V.; Morehead, Jr. A. T. J. Am. Chem. Soc. 2005, 127, 16042-16043. (c) Sato, Y.; Ohnishi, Y.; Mori, M. Angew. Chem. Int. Ed. 2002, 41, 1218-1221. (d) Tanaka, K.; Fu, G. C. J. Am. Chem. Soc. 2003, 125, 8078-8079. (e) Tanaka, K.; Fu, G. C. J. Am. Chem. Soc. 2001, 123, 11492 11493 (f) Larock, R. C.; Oertle, K.; Potter, G. F. J. Am. Chem. Soc. 1980, 102, 190-197.

3. Selected examples for chelation-assisted hydroacylations, see: (a) von Delius, M.; Le, C. M.; Dong, V. M. J. Am. Chem. Soc. 2012, 134, 15022-15032. (b) Coulter, M. M.; Kou, K. G. M.; Galligan, B.; Dong, V. M. J. Am. Chem. Soc. 2010, 132, 16330-16333. (c) Murphy, S. K.; Petrone, D. A.; Coulter, M. M.; Dong, V. M. Org. Lett. 2011, 13, 6216-6219. (d) Zhang, H.-J.; Bolm, C. Org. Lett. 
2011, 13, 3900-3903. (e) Chaplin, A. B.; Hooper, J. F.; Weller, A. S.; Wills, M. C. J. Am. Chem. Soc. 2012, 134, 4885-4897. (f) Moxham, G. L.; Randell-Sly, H. E.; Brayshaw, S. K.; Weller, A. S.; Willis, M. C. Chem.-Eur. J. 2008, 14, 8383-8397. (g) Osborne, J. D.; Willis, M. C. Chem. Commun. 2008, 5025-5027. (h) Moxham, G. L.; Randell-Sly, H. E.; Brayshaw, S. K.; Woodward, R. L.; Weller, A. S.; Willis, M. C. Angew. Chem., Int. Ed. 2006, 45, 7618-7622. (i) Jun, C.-H.; Lee, H.; Hong, J.-B. J. Org. Chem. 1997, 62, 1200-1201. (j) Kokubo, K.; Matsumasa, K.; Miura, M.; Nomura, M. J. Org. Chem. 1997, 62, 4564-4565; (k) Murphy, S. K.; Bruch, A.; Dong, V. M. Angew. Chem. Int. Ed. 2014, 53, 2455-2459.

4. (a) Kondo, T.; Akazome, M.; Tsuji, Y.; Watanabe, Y. J. Org. Chem. 1990, 55, 1286-1291. (b) Kondo, T.; Tsuji, Y.; Watanabe, Y. Tetrahedron Lett. 1987, 28, 6229-6230.

5. Selected examples for oxidative and reductive formal hydroacylations, see: (a) Han, S. B.; Kim, I.-S.; Han, H.; Krische, M. J. J. Am. Chem. Soc. 2009, 131, 6916-6917. (b) Bower, J.; Skucas, E.; Patman, R. L.; Krische, M. J. J. Am. Chem. Soc. 2007, 129, 15134-15135. (c) Skucas, E.; Bower, J.; Krische, M. J. J. Am. Chem. Soc. 2007, 129, 12678-12679. (d) Shibahara, F.; Bower, J. F.; Krische, M. J. J. Am. Chem. Soc. 2008, 130, 14120-14122. (e) Shibahara, F.; Bower, J. F.; Krische, M. J. J. Am. Chem. Soc. 2008, 130, 6338-6339. (f) Patman, R. L.; Chaulagain, M. R.; Williams, V. M.; Krische, M. J. J. Am. Chem. Soc. 2009, 131, 2066-2067. (g) Omura, S.; Fukuyama, T.; Horiguchi, J.; Murakami, Y.; Ryu, I. J. Am. Chem. Soc. 2008, 130, 14094-14095. (h) Hatanaka, S.; Obora, Y.; Ishii, Y. Chem.-Eur. J. 2010, 16, 1883-1888.

6. Fujihara, T.; Tatsumi, K.; Terao, J.; Tsuji, Y. Org. Lett. 2013, 15, 2286-2289.

7. (a) Gooßen, L. J.; Rodoríguez, N.; Gooßen, K. Angew. Chem. Int. Ed. 2008, 47, 3100-3120.

8. (a) Kakino, R.; Yasumi, S.; Shimizu, I.; Yamamoto, A. Bull. Chem. Soc. Jpn. 2002, 75, 137-148. (b) Gooßen, L. J.; Ghosh, K. Chem. Commun. 2001, 2084-2085. (c) Gooßen, L. J.; Ghosh, K. d Eur J. Org. Chem. 2002, 3254-3267.

9. (a) Bercot, E. A.; Rovis, T. J. Am. Chem. Soc. 2004, 126, 1024810249. (b) Wang, D.; Zhang, Z. Org. Lett. 2003, 5, 4645-4648.

10. (a) Hong, Y. T.; Barchuk, A.; Krische, M. J. Angew. Chem. Int. Ed. 2006, 45, 6885-6888. (b) Kokubo, K.; Miura, M.; Nomura, M. Organometallics 1995, 14, 4521-4524.

11. (a) Kokubo, K.; Matsumasa, K.; Nishinaka, Y.; Miura, M.; Nomura, M. Bull. Chem. Soc. Jpn. 1999, 72, 303-311. (b) Osborne, J. D.; Randell-Sly, H. E.; Currie, G. S.; Cowley, A. R.; Willis, M. C. J. Am. Chem. Soc. 2008, 130, 17232-17233.

12. Nagayama, K.; Shimizu, I.; Yamamoto, A. Bull. Chem. Soc. Jpn. 2001, 74, 1803-1815.

13. Fujihara, T.; Cong, C.; Terao, J.; Tsuji, Y. Adv. Synth. Catal. 2013, $355,3420-3424$.

14. (a) Nagayama, K.; Shimizu, I.; Yamamoto, A. Chem. Lett. 1995, 367-368. (b) Nagayama, K.; Kawataka, F.; Sakamoto, M.; Shimizu, I.; Yamamoto, A. Bull. Chem. Soc. Jpn. 1999, 74, 573580 .

15. Armarego, W. L. F.; Chai, C. L. L. Purification of Laboratory Chemicals, 5th ed.; Burrerworth-Heinemann: Oxford, U. K., 2003.

16. Fujihara, T.; Cong, C.; Terao, J.; Tsuji, Y. Synlett 2012, 23, 23892392.

\section{Supplementary Material}

Supplementary material that may be helpful in the review process should be prepared and provided as a separate electronic file. That file can then be transformed into PDF format and submitted along with the manuscript and graphic files to the appropriate editorial office. 